\title{
Adrenomedullin expression in epithelial ovarian cancers and promotes HO8910 cell migration associated with upregulating integrin $\alpha 5 \beta 1$ and phosphorylating FAK and paxillin
}

\author{
Boya Deng ${ }^{1}$, Siyang Zhang ${ }^{2}$, Yuan Miao ${ }^{3}$, Zhuang $\mathrm{Han}^{4}$, Xiaoli Zhang ${ }^{3}$, Fang Wen ${ }^{1 *}$ and Yi Zhang ${ }^{1 *}$
}

\begin{abstract}
Background: Epithelial ovarian cancer (EOC) is one of the leading causes of cancer deaths in women worldwide. Adrenomedullin (AM) is a multifunctional peptide which presents in various kinds of tumors.

Methods: In this study, we characterized the expression and function of AM in epithelial ovarian cancer using immunohistochemistry staining. Exogenous AM and small interfering RNA (siRNA) specific for AM receptor CRLR were treated to EOC cell line HO8910. Wound healing assay and flow cytometry were used to measure the migration ability and expression of integrin $\alpha 5$ of $\mathrm{HO} 8910$ cells after above treatments. Western blot was used to examine the phosphorylation of FAK and paxillin.

Results: We found that patients with high AM expression showed a higher incidence of metastasis, larger residual size of tumors after cytoreduction and shorter disease-free and overall survival time. Exogenous AM induced ovarian cancer cell migration in time- and dose- dependent manners. AM upregulated the expression of integrin $\alpha 5$ and phosphorylation of FAK, paxillin as well.

Conclusions: Our results suggested that AM contributed to the progression of EOC and had additional roles in EOC cell migration by activating the integrin $\alpha 5 \beta 1$ signaling pathway. Therefore, we presumed that AM could be a potential molecular therapeutic target for ovarian carcinoma.
\end{abstract}

Keywords: Epithelial ovarian cancer, AM, Carcinogenesis, Progression, Migration, Integrin a5 $\beta 1$, FAK, Paxillin

\section{Background}

Epithelial ovarian cancer (EOC) is the sixth most common cancer and the fifth leading cause of cancer mortality in women worldwide [1]. This lethal gynecological malignancy is commonly diagnosed at a late stage due to the silent early stage and easily metastasis. Many advances took place in the pathological study and in understanding the mechanisms involved in EOC progression, details still need further investigations $[2,3]$. Therefore, this is an urgent need of more effective and new molecular targeted therapies for EOC.

\footnotetext{
* Correspondence: wenfang64@hotmail.com; syzi@163.com 'Department of Gynecology, The First Hospital of China Medical University, Shenyang 110001, China

Full list of author information is available at the end of the article
}

Adrenomedullin (AM) is a 52-amino-acid peptide first isolated from human pheochromocytoma [4]. It belongs to a family of peptides with calcitonin gene-related peptide (CGRP) and Amylin [5]. AM was identified as a major regulator of carcinogenesis and tumor progression, and autocrine loop of AM was targeted as new strategies against human cancers [6-8]. AM gene expression was proved to be associated with histological grade and poor prognosis of ovarian cancer [9]. The expression of its receptor calcitonin receptor-like receptor CRLR together with modulation factors RAMP2/ RAMP3 were also found in EOC tissues and OVCAR3 cells $[10,11]$. Our previous study had found that AM was autocrined in EOC cell line CAOV3 by bFGF stimulation [12].Thus we supposed that AM may play an important role in EOC progression.

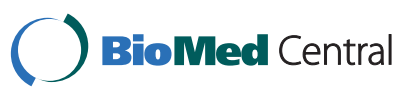

(c) 2012 Deng et al; licensee BioMed Central Ltd. This is an Open Access article distributed under the terms of the Creative Commons Attribution License (http://creativecommons.org/licenses/by/2.0), which permits unrestricted use, distribution, and reproduction in any medium, provided the original work is properly cited. 
Integrins are family of transmembrane proteins, which are composed of 2 subunits as $\alpha$ - and $\beta$ - formed heterodimer, and work as receptors of extracellular matrix (ECM) [13]. Integrins received and transmitted the signal from ECM into cells and modified various function of cells including shape, motility, and involved in EOC metastasis $[14,15]$. It was well accepted that integrin $\alpha 5$ specifically bound to integrin $\beta 1$ to form specific receptor for fibronectin (FN). Activated integrin $\alpha 5 \beta 1$ could activate the focal adhension kinase (FAK) and Src, which consequently promoted cancer cells migration and invasion via activating various skeleton proteins, such as paxillin. It was reported that overexpression of integrin $\alpha 5 \beta 1$ predicted poor prognosis for EOCs [16]. And integrin $\alpha 5 \beta 1$ promoted ovarian cancer cells invasion by directly activating c-Met followed by FAK activation [17].

In this study, we evaluated AM expression in EOC tissues by immunohistological staining to analyze possible correlations between AM expression and the clinical determination of FIGO staging, differentiation, and prognosis. We further probed the biological features of AM by assaying cell migration and potential mechanism underlying this.

\section{Methods}

\section{Cell culture and reagents}

EOC cell line HO8910 cells were maintained in RPMI 1640 medium with $10 \%$ fetal bovine serum (Thermo Scientific Hyclone, USA), supplemented with 100 units/ $\mathrm{ml}$ penicillin and $100 \mathrm{units} / \mathrm{ml}$ streptomycin (Sigma, USA) and maintained at $37^{\circ} \mathrm{C}$ with $5 \% \mathrm{CO}_{2}$. When confluent, cells were treated with 100 nM AM (Phoenix Pharmaceuticals, USA). Cells were pretreated by $1 \mathrm{nM}$ AM22-52 (Phoenix Pharmaceuticals, USA), or by $5 \mu \mathrm{g} /$ $\mathrm{ml}$ the anti-integrin $\alpha 5 \beta 1$ monoclonal blocking antibody (mAb) (BD Biosciences, USA) $1 \mathrm{~h}$ followed by AM.

\section{Tissue samples}

For immunohistochemical analysis, EOCs $(\mathrm{n}=96)$ were collected from surgical specimens originating from the First Affiliated Hospital of China Medical University between 2000 and 2008. Clinical data were obtained from clinical databases and tumors were staged according to International Federation of Gynecology and Obstetrics (FIGO) guidelines. There were 82 cases that had complete follow-up records.

\section{Immunohistochemical staining and evaluation}

All paraffin sections were deparaffinized and rehydrated. The sections were hematoxylin-and-eosin (HE) stained to confirm histological diagnosis by two pathologists (Yuan Miao and Xiaoli Zhang) according to the World Health Organization (WHO) classifications. Sections were subjected to antigen retrieval by heating in TrisEDTA buffer at $\mathrm{pH} 8.0$ in an autoclave sterilizer for 2 min. A blocking solution consisting of $3 \% \mathrm{H}_{2} \mathrm{O}_{2}$ and $5 \%$ bovine serum albumin was used to block endogenous peroxidase activity and non-specific binding. The sections were incubated with goat anti-AM antibody (10 $\mu \mathrm{g} / \mathrm{ml}$; R\&D, USA) overnight at $4^{\circ} \mathrm{C}$. On the next day, the sections were treated with the secondary antibody and SP complex (streptavidin-peroxidase) for $40 \mathrm{~min}$ (Maixin Biotechnology, Fujian, China). Binding sites were visualized with 3,3'-diainobenzidine (DAB) after 1 min incubation (Maixin Biotechnology, Fujian, China). After counterstaining with Mayer's hematoxylin, the sections were dehydrated and mounted. For the negative control, phosphate-buffered saline (PBS) was used instead of the primary antibody.

We evaluated the cytoplasmic and membrane distribution of AM protein for statistical analysis in EOCs. One hundred cells were randomly selected and AM distribution was manually counted from 5 representative $400 \times$ fields of each section by two independent observers (Yuan Miao and Boya Deng) in a blinded study. The percentage of cells positive for AM cytoplasmic and membrane expression was graded and counted as follows: $(0=$ negative; $1=1-50 \% ; 2=50-74 \% ; 3 \geq 75 \%)$. The staining intensity score was graded as follows for cytoplasmic expression ( 1 = weak; 2 = intermediate; and 3 = strong). The scores for AM positivity and staining intensity were multiplied to obtain a final score, which determines AM expression as $(-=0 ;+=1-2 ;++=3-4 ;+++=6-9)$.

\section{Western blot}

Cells were washed twice with ice-cold PBS, collected and homogenized on ice in 10 volumes $(\mathrm{w} / \mathrm{v})$ of lysis buffer containing $20 \mathrm{mM}$ Tris- $\mathrm{HCl}, 1 \mathrm{mM}$ EDTA, 50 $\mathrm{mM} \mathrm{NaF}, 50 \mathrm{mM} \mathrm{NaCl}, 1 \mathrm{mM} \mathrm{Na} \mathrm{VO}_{4}, 1 \%$ Triton X100, AND $1 \mathrm{mM}$ PMSF. The homogenate was centrifuged at $15,000 \mathrm{rpm}$ for $30 \mathrm{~min}$ at $4^{\circ} \mathrm{C}$. The supernatant was collected and protein content was determined using the BCA assay (Beyotime Institute of Biotechnology, Jiangsu, China). Protein was separated by $10 \%$ SDSPAGE and then transferred to PVDF blotting membranes, which were then blocked for $2 \mathrm{~h}$ in $5 \%$ defatted milk in Tris-buffered saline containing Tween-20 (TBST, 10 mM Tris- $\mathrm{HCl}, 150 \mathrm{mM} \mathrm{NaCl}, 0.1 \%$ Tween$20)$. For immunoblotting, the membrane was incubated at $4{ }^{\circ} \mathrm{C}$ overnight with anti- $\beta$-actin $(1: 1000$, Keygen Biotech, China), anti-CRLR (1:1000, Phoenix, USA), antiFAK (1:500), anti-FAK pY397 (1:500), anti-paxillin (1:500), anti-paxillin pY118 (1:500), which were all from Santa Cruz company (Santa Cruz, USA). Then, it was rinsed with TBST three times and incubated with corresponding horseradish peroxidase conjugated IgG antibodies (1:2000, Zhongshan Golden Bridge Biotechnology, 
Beijing, China) for $2 \mathrm{~h}$. Immunoreactive bands were visualized using ECL (Beyotime Institute of Biotechnology, Jiangsu, China). The MF-ChemiBIS 3.2 Imaging System (DNR Bio-Imaging Systems, Israel) was used for image capture. The optical density (OD) of each band was measured using Image J software.

\section{Migration assay}

Cells were plated on 24 well-plates at $5 \times 10^{4} /$ well. The next day, cells were washed with PBS and wounds were created by scraping with a sterilized pipette tip. After washed twice with PBS, cells were incubated in RPMI1640 containing $0.5 \%$ fetal bovine serum. The wound closure was monitored at $0-12 \mathrm{~h}$. The wound areas were observed by an inverted microscope (OlympusIX71, Japan) and measured by Image $J$ at the exact place and the healing percentages were calculated. Each test was performed triplicates.

\section{CRLR knockdown with siRNA}

The CRLR-specific small interfering RNA (siRNA) (\#42272) and scrambled siRNA (\#4611) were designed and synthesized by Ambion (USA). Using Lipofectamine 2000 (Invitrogen, CA, USA), HO8910 cells were transfected with siRNAs following the manufacturer's protocol. Cells were cultured with fresh medium $6 \mathrm{~h}$ after transfection.

\section{Real-time PCR}

To confirm the effection of siRNA, we carried out realtime RT-PCR by using SYBR Premix Ex Taq ${ }^{\mathrm{TM}}$ II kit (Takara, Japan). Total RNA was extracted by RNAiso Plus (Takara, Japan) according to the manufactor's protocol. 2 microgram of total RNA were subjected to cDNA synthesis by AMV transctriptase and the random primer (Takara, Otsu, Japan). Oligonucleotide primers for CRLR were designed as follows: forward: 5'GGATGGCTCTGCTGGAACGATGT -3' and reverse: 5'-TGCAGTCTTCACTTTCTCGTGGG -3' (204 bp). The primers for the internal control, $\beta$-actin were forward: 5' - AAGGCTGTGGGCAAGG -3' and reverse: 5'TGGAGGAGTGGGTGTCG -3' (238 bp). PCR amplification of cDNA was performed in $20 \mu \mathrm{L}$ mixtures containing $10 \mu \mathrm{L}$ SYBR Premix Ex Taq $(\times 2)$ with $0.08 \mu \mathrm{L}$ of each primer, $0.4 \mu \mathrm{L}$ of ROX Reference Dye, and $1 \mu \mathrm{L}$ of template cDNA $(50 \mu \mathrm{g} / \mu \mathrm{L})$. The protocol included the following parameters: an initial $30 \mathrm{~s}$ of incubation at $94^{\circ}$ $\mathrm{C}$ followed by 40 cycles of denaturation at $95^{\circ} \mathrm{C}$ for $5 \mathrm{~s}$ and annealing at $60^{\circ} \mathrm{C}$ for $35 \mathrm{~s}$. Each experiment was done at least in triplicate, and the gene expression levels were calculated by $\Delta \Delta \mathrm{Ct}$ method.

\section{Flow cytometer analysis}

To study the cell surface expression of integrin $\alpha 5$ antiintegrin $\alpha 5 \mathrm{mAb}$ (IIA1) (BD Biosciences, USA) were used at the recommended concentrations [18]. Cells were incubated with antibody for $30 \mathrm{~min}$ at $4^{\circ} \mathrm{C}$ and washed with PBS 3 times. Then cells were incubated with PE-conjugated IgG (1:300, Beijing Zhongshan Golden Bridge Biotechnology Co. China) for $45 \mathrm{~min}$ at $4^{\circ} \mathrm{C}$, washed and fixed in $2 \%$ formaldehyde. Cells immunofluorescent contents were evaluated with a FACSCalibur flow cytometer (BD Biosciences, USA).

\section{Statistical analysis}

SPSS 16.0 software was employed for all data analysis. Statistical evaluation was performed using the Spearman correlation test to analyze the rank data between the AM expression and clinicopathological parameters. Overall and disease-free survival curves were generated using the Kaplan-Meier method, and the differences between the curves were assessed using the Log-rank test. A COX proportional hazard model was used to determine the factors related to survival time. And oneway ANOVA was used to analyze the wound healing rates between groups and realtime PCR results as well. $P<0.05$ was considered as statistically significant.

\section{Results}

\section{Clinical significance of AM expression in ovarian carcinomas}

There were 96 EOC cases eligible for our study. The age of patients ranged from 30 to 77 years $($ median $=52$ ). Of all the cases, 17 were FIGO-I ovarian carcinomas, 19 were FIGO-II stage, 53 were FIGO-III stage and 7 were FIGO-IV stage. AM was mainly expressed in the cytoplasm and membrane of EOCs, seldom in nuclear of EOC cells, and was also expressed in the endothelial vessel cells and stromal cells in tumors, as shown in Figure 1 using immunostaining. In ovarian malignant tumor samples, $91.67 \%$ of cases (88/96) showed AM protein expression in the membrane and the cytoplasm of EOCs. As shown in Table 1, AM expression was positively correlated with FIGO stage $(P=0.003)$, residual tumor after initial laparotomy $(P=0.000)$, but not with age, degree of differentiation, or serum CA125 before operation.

Follow-up information was available for 82 EOC patients with survival periods ranging from 2 to 89 months (median $=36$ months). Survival curves for EOCs were stratified according to AM expression (Figure 2). By using the Kaplan-Meier method, we indicated that both survival time and disease-free time for patients were linked to AM expression status (diseasefree time, $P=0.020$, Figure $2 \mathrm{~A}$; overall survival time, $P$ $=0.030$, Figure $2 \mathrm{~B}$ ). By using univariate Cox propor tional analysis, AM expression was statistically correlated to disease-free survival and overall survival $(P<$ 0.05 , Table 2). By using multivariate Cox proportional 

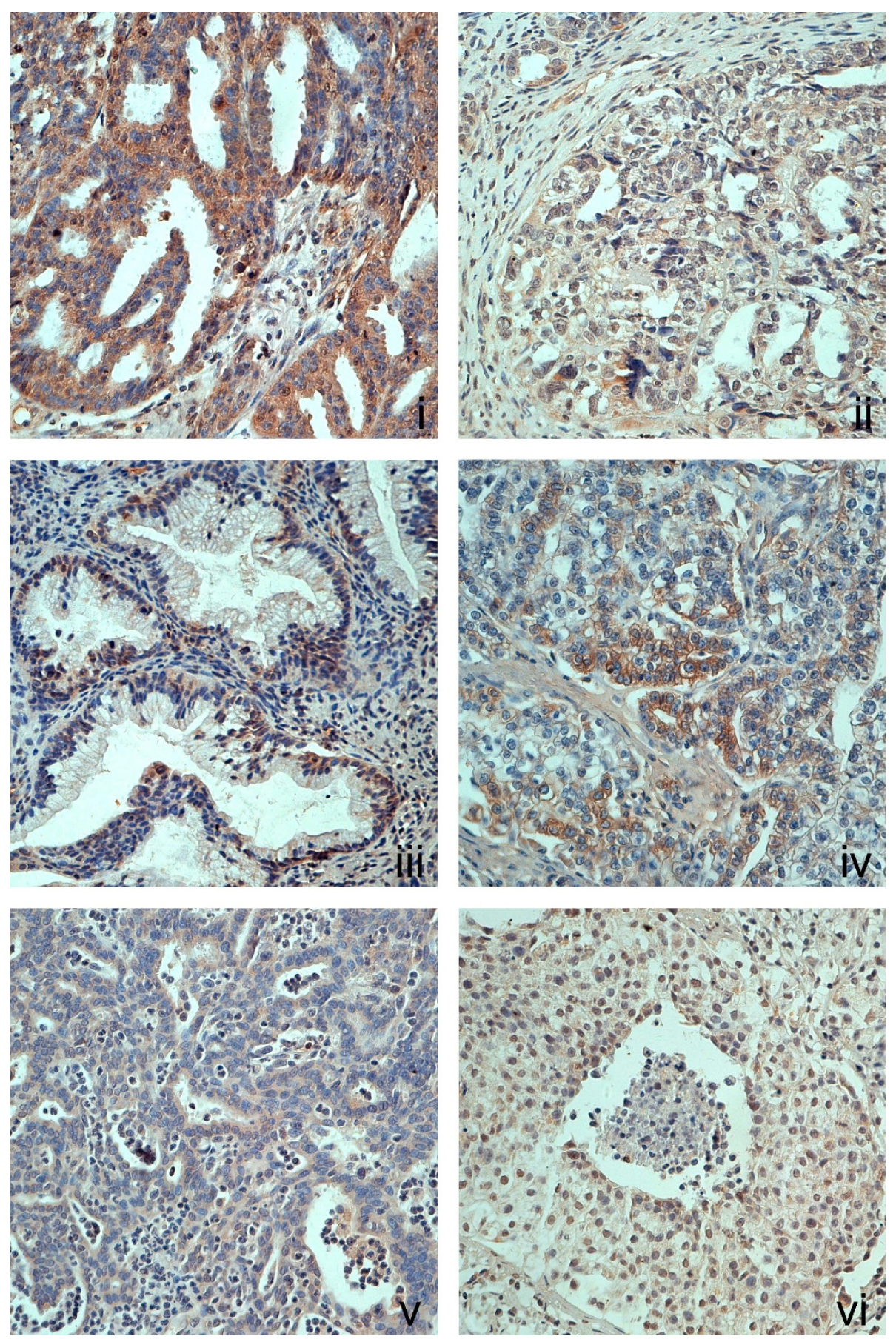

Figure 1 AM expression in EOC samples. Immunohistochemical analysis of AM expression in EOCs. EOCs: FIGO III stage serous (i), FIGO I stage serous (ii), mucinous (iii), clear-cell (iv), endometrioid (v) ovarian cancer, malignant Brenner tumor of ovary (vi).

analysis, considering all the clinical parameters and AM expression, FIGO staging was an independent factor of disease-free survival prognosis prediction, and both age and disease-free time were independent factors predicted EOC over-all survival prognosis $(P<$ 0.05, Table 3).

\section{AM promoted ovarian cancer cells migration}

HO8910 cells migration was enhanced with exogenous AM treatment in both dose-dependent and time dependent manners, as shown in Figure 3. Cell migration rates were consequently increased when cells were treated with different dose of $\mathrm{AM}(1,10,100 \mathrm{nM})$ for $12 \mathrm{~h}$ 
Table 1 Relationship between AM expression and clinicopathological features in EOCs

\begin{tabular}{|c|c|c|c|c|c|c|}
\hline \multirow[t]{2}{*}{ Clinicopathological features } & \multirow[t]{2}{*}{$\mathrm{n}$} & \multicolumn{5}{|c|}{ AM expression } \\
\hline & & - & + & ++ & +++ & $P$ value \\
\hline Age(years) & & & & & & 0.705 \\
\hline$<55$ & 56 & 5 & 18 & 12 & 21 & \\
\hline$\geq 55$ & 40 & 3 & 9 & 9 & 19 & \\
\hline Histotype & & & & & & 0.155 \\
\hline Serous & 75 & 7 & 17 & 17 & 34 & \\
\hline Non serous & 21 & 1 & 10 & 4 & 6 & \\
\hline Residual tumor after initial laparotomy & & & & & & $0.000^{*}$ \\
\hline$<1 \mathrm{~cm}$ & 42 & 1 & 21 & 10 & 10 & \\
\hline$\geq 1 \mathrm{~cm}$ & 53 & 7 & 6 & 11 & 29 & \\
\hline Undetermined & 1 & 0 & 0 & 0 & 1 & \\
\hline Differentiation & & & & & & 0.199 \\
\hline Well-differentiated & 27 & 4 & 11 & 6 & 6 & \\
\hline Moderately-differentiated & 23 & 1 & 8 & 3 & 11 & \\
\hline Poorly-differentiated & 39 & 3 & 7 & 11 & 18 & \\
\hline Undetermined & 7 & 0 & 1 & 1 & 5 & \\
\hline FIGO staging & & & & & & $0.003^{*}$ \\
\hline । & 17 & 1 & 10 & 1 & 5 & \\
\hline$\|$ & 19 & 0 & 10 & 4 & 5 & \\
\hline III & 53 & 6 & 7 & 13 & 27 & \\
\hline IV & 7 & 1 & 0 & 3 & 3 & \\
\hline Serum CA125 & & & & & & 0.301 \\
\hline$\geq 500$ & 52 & 5 & 11 & 13 & 23 & \\
\hline$<500$ & 41 & 3 & 16 & 7 & 15 & \\
\hline Undetermined & 3 & 0 & 0 & 1 & 2 & \\
\hline
\end{tabular}

${ }^{*} P<0.05$

$\mathrm{EOC}=$ epithelial ovarian cancer; $\mathrm{AM}=$ Adrenomedullin; FIGO = International Federation of Gynecology and Obstetrics

(Figure 3A). Recovery rates were $29.23 \pm 4.15 \%$ with negative control, $43.06 \pm 2.63 \%$ with $1 \mathrm{nM}(P=0.008)$, $51.58 \pm 2.93 \%$ with $10 \mathrm{nM}(P=0.002), 62.61 \pm 4.51 \%$ with $100 \mathrm{nM}(P=0.001)$, respectively. A time course experiment was provided with AM (100 nM) by different incubation periods $(1 \mathrm{~h}, 6 \mathrm{~h}$, and $12 \mathrm{~h})$. And the AM effect was increased gradually at $2 \mathrm{~h}(P=0.023)$, and reached the maximum at $12 \mathrm{~h}(P=0.000$, Figure 3B). AM22-52, the receptor antagonist of AM, inhibited HO8910 cell migration $(P=0.024)$, and significantly inhibited the effect of AM on the migration of cells $(P=$ 0.015 , Figure $3 C$ ). Previously knockdown of AM receptor CRLR by siRNA effectively aborted the expression of mRNA $(P=0.013$, Figure $4 \mathrm{~A})$ and protein expression of CRLR in HO8910 cells (Figure 4B). When cells were transfected with CRLR siRNA, the effect of AM on cell migration was decreased consequently $(P=0.001$, Figure 4C).

HO8910 cells were treated with exogenous AM (100 $\mathrm{nM}$ ) before subjecting to cell migration assay. Wound healing percentages were measured and calculated at time point of $3 \mathrm{~h}, 6 \mathrm{~h}, 12 \mathrm{~h}(\mathrm{~A})$. Different concentration
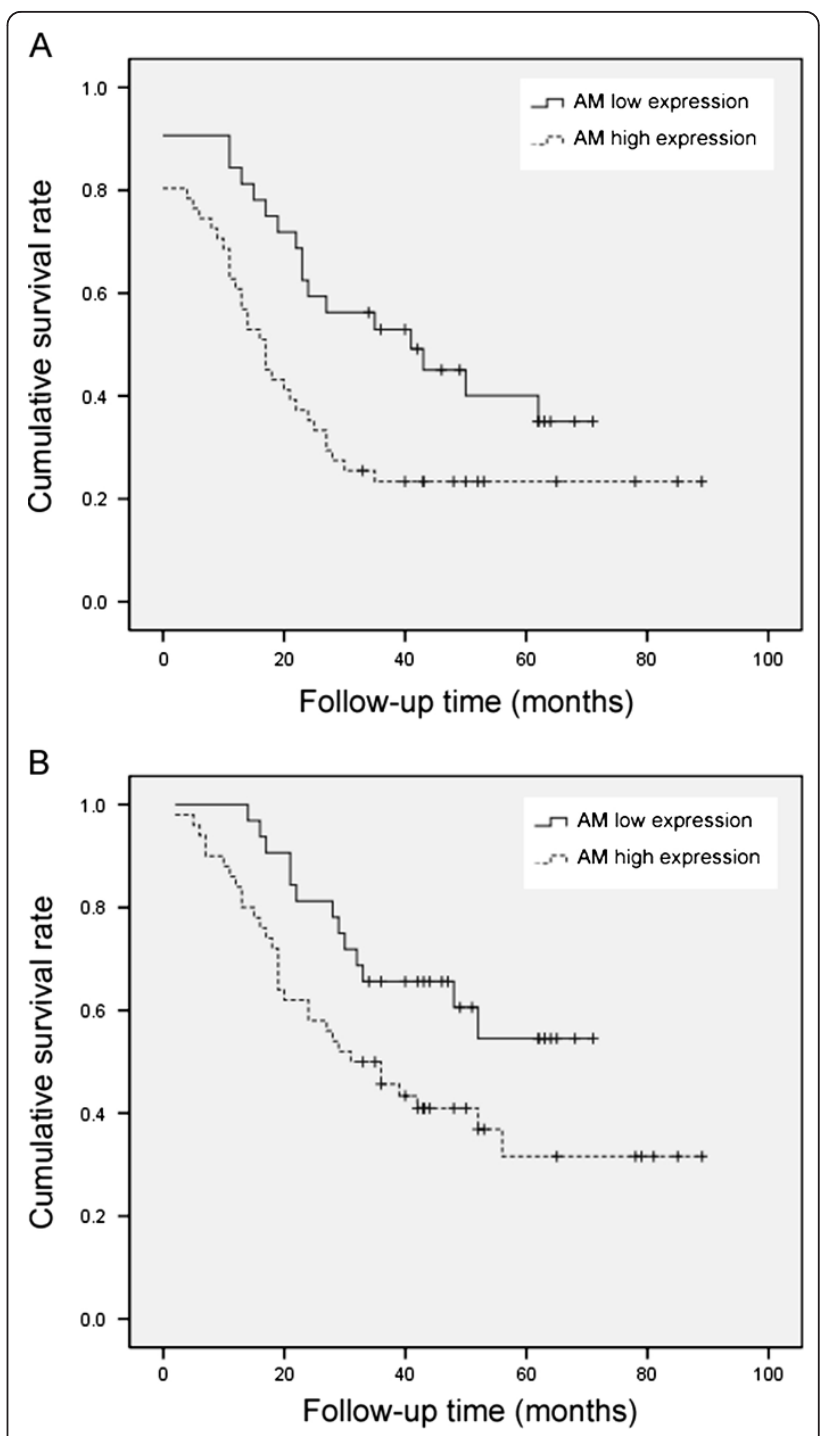

Figure 2 Correlation between AM status and EOC patient prognosis. Kaplan-Meier curves for disease-free survival rate of EOC patients according to the AM expression status (A); Kaplan-Meier total survival curves of EOC patients according to the AM expression status (B). Both survival time and disease-free time of patients were linked to AM expression status (Log-rank test, $P=0.020 ; P=0.030$ ).

of $\operatorname{AM}(1,10,100 \mathrm{nM})$ were administrated to HO8910 cells and wound healing percentages were calculated at 24 h (B). AM (22-52) inhibited HO8910 cells migration and also antagonized the AM (100 nM) effect on migration $(\mathrm{C})$. Each test was repeated triplicates

\section{AM enhanced HO8910 cell migration was linked to the activation of integrin $\alpha 5 \beta 1$ signaling pathway}

By using flow cytometry, we studied the effects of AM on the expression of integrin $\alpha 5$. At $12 \mathrm{~h}$ after providing AM (100 nM), significant increased integrin $\alpha 5$ expression was observed in AM treated cells (Figure 5A). We 
Table 2 Univariate Cox proportional hazards regression analyses of clinicopathological variables and AM expression for EOC patient outcome

\begin{tabular}{|c|c|c|c|c|}
\hline \multirow{2}{*}{ Variables } & \multicolumn{2}{|c|}{ Disease-free survival } & \multicolumn{2}{|c|}{ Overall survival } \\
\hline & $\begin{array}{c}\text { Relative risk } \\
(95 \% \mathrm{Cl})\end{array}$ & $P$ value & $\begin{array}{c}\text { Relative risk } \\
(95 \% \mathrm{Cl})\end{array}$ & $P$ value \\
\hline Age( $\geq 55$ years $)$ & $1.663(0.985-2.808)$ & 0.057 & $2.174(1.201-3.935)$ & $0.010^{*}$ \\
\hline Differentiation & $1.542(1.084-2.193)$ & $0.016^{*}$ & $1.449(0.971-2.161)$ & 0.069 \\
\hline FIGO staging $(I-I V)$ & $4.883(1.937-12.309)$ & $0.001^{*}$ & $5.285(1.630-17.131)$ & $0.006^{*}$ \\
\hline \multicolumn{5}{|l|}{ Residual tumor after } \\
\hline initial laparotomy $(\geq 1 \mathrm{~cm})$ & $2.776(1.598-4.824)$ & $0.000^{*}$ & $2.760(1.458-5.227)$ & $0.002^{*}$ \\
\hline AM expression & $1.878(1.081-3.265)$ & $0.025^{*}$ & 2.014(1.052-3.852) & $0.035^{*}$ \\
\hline Disease-free time & & & $0.925(0.904-0.946)$ & $0.000^{*}$ \\
\hline
\end{tabular}

${ }^{*} P<0.05, P$ value were calculated by Wald statistics

found that the blocking antibody against integrin $\alpha 5 \beta 1$ effectively downregulated the cell migration promotion effects of $\mathrm{AM}(\mathrm{P}=0.000$, Figure $5 \mathrm{~B})$. We also found that AM induced the phosphorylation of FAK and paxillin. Treatment with AM (100 nM) significantly increased the phosphorylation status of FAK 397 at 15 min time point, and paxillin 118 at $60 \mathrm{~min}$ (Figure 5C). And blocking the integrin $\alpha 5 \beta 1$ activity significantly inhibited the phosphorylation of FAK and paxillin by AM (Figure 5D).

\section{Discussion}

AM is a peptide and pathologically elevated in various tumors. We described the relationship between AM expression and clinicopathological parameters of 96 cases of EOC with immunohistochemical analysis in the

Table 3 Multivariate Cox proportional hazards regression analyses of clinicopathological variables and AM expression for EOC patient outcome

\begin{tabular}{|c|c|c|c|c|}
\hline \multirow{2}{*}{ Variables } & \multicolumn{2}{|c|}{ Disease-free survival } & \multicolumn{2}{|c|}{ Overall survival } \\
\hline & $\begin{array}{c}\text { Relative risk } \\
(95 \% \mathrm{Cl})\end{array}$ & $P$ value & $\begin{array}{c}\text { Relative risk } \\
(95 \% \mathrm{Cl})\end{array}$ & $P$ value \\
\hline Age $(\geq 55$ years $)$ & $1.663(0.983-2.813)$ & 0.058 & $1.880(1.012-3.495)$ & $0.046^{*}$ \\
\hline Differentiation & $1.061(0.785-1.434)$ & 0.702 & $0.964(0.689-1.349)$ & 0.830 \\
\hline $\mathrm{FIGO}$ staging $(\mathrm{II-IV})$ & 4.886(1.938-12.322) & $0.001^{*}$ & 0.949(0.219-4.118) & 0.944 \\
\hline \multicolumn{5}{|l|}{ Residual tumor after } \\
\hline initial laparotomy $(\geq 1 \mathrm{~cm})$ & $1.514(0.794-2.888)$ & 0.208 & $1.285(0.651-2.537)$ & 0.469 \\
\hline AM expression & $1.307(0.735-2.324)$ & 0.362 & $0.868(0.426-1.769)$ & 0.697 \\
\hline Disease-free time & & & $0.927(0.906-0.948)$ & $0.000^{*}$ \\
\hline
\end{tabular}

${ }^{*} P<0.05, P$ value were calculated by Wald statistics.

$\mathrm{Cl}=$ confidence interval.

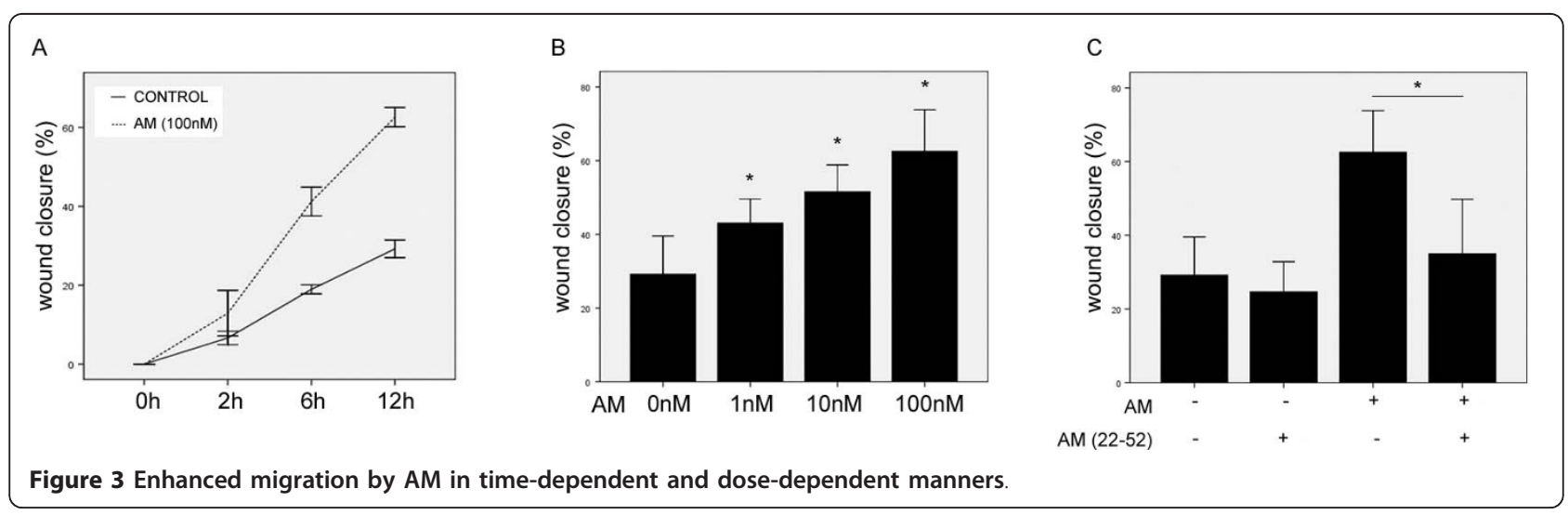




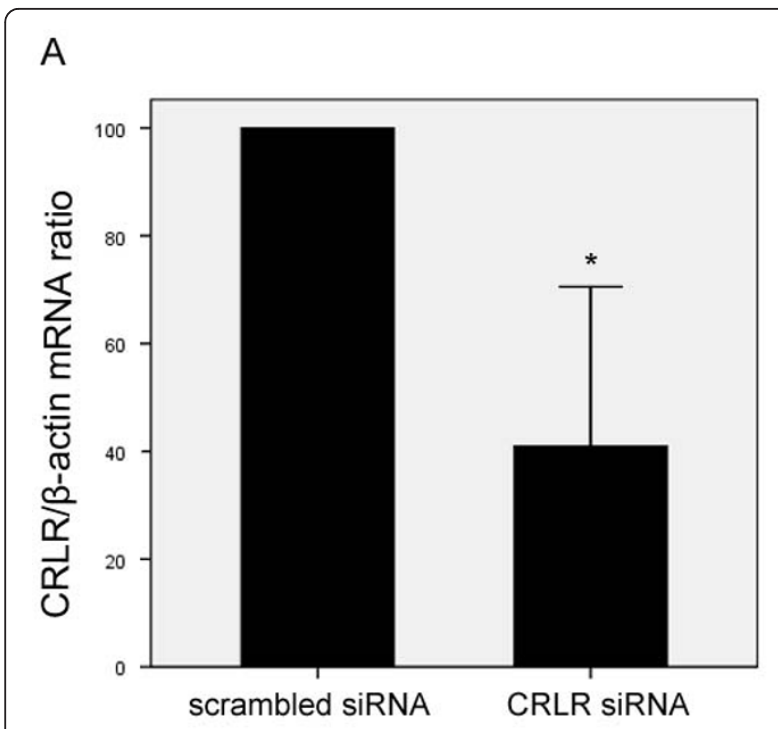

B

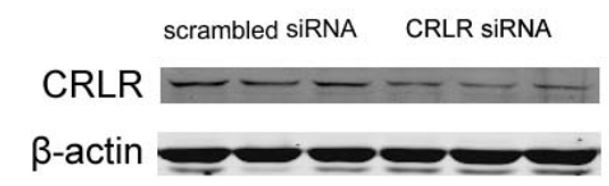

C

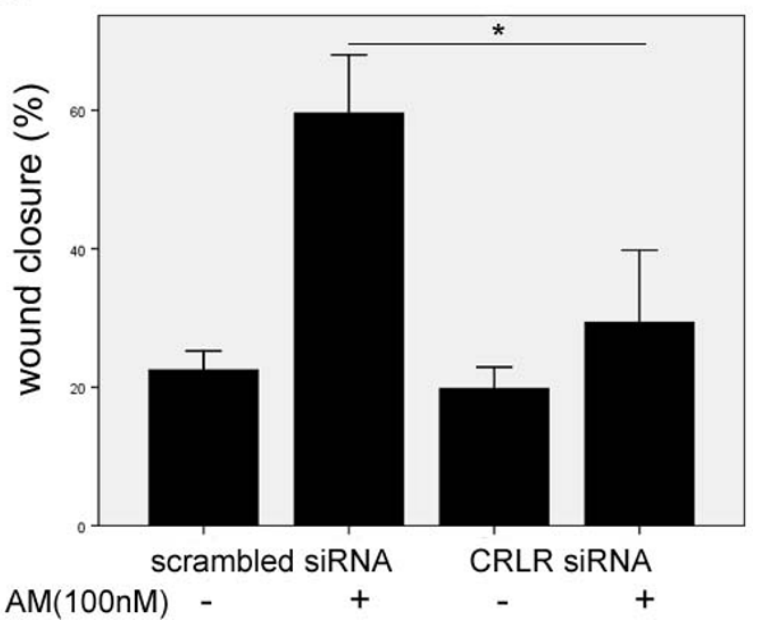

Figure 4 Down-regulation of CRLR expression in HO8910 cells inhibited influence of exogenous $A M$ on cell migration.

Reduced CRLR mRNA expression (A) and protein expression (B) were determined by real-time PCR analysis or western blot in CRLR siRNA transfected cells, compared with scrambled siRNA transfected cells. After cells were transfected by CRLR siRNA, the effect of AM on cells migration was decreased consequently (C).

present study. We found that AM expression was positively related to the FIGO stage and with residual tumor size after initial surgical treatment. These data indicated that expression of AM might contribute to more aggressive behavior of EOC, and participate in EOC progression. AM high expression showed shorter disease free time and over-all survival time, which was similar with Hata's research by analyzing AM mRNA expression in 60 cases of EOCs [9]. We separately evaluated prognostic value of various factors by univariate COX proportional analysis, and found that AM expression was significantly associated with both the disease free survival and over-all survival. By using multivariant COX proportional analysis which evaluated all variants together, FIGO staging and age were independent factors of EOC prognosis prediction.

In order to further investigate the effects of AM on EOC progression, we provided exogenous AM to EOC cell line HO8910. The migratory rate of HO8910 was significantly increased in AM treated groups, which was blocked by the receptor antagonist AM22-52. Then, we endogenously decreased the AM receptor CRLR expression by specific siRNA, and found that CRLR downregulation mostly blocked the positive effect of AM on cell migration. Thus we considered that CRLR played crucial roles in AM promoting migration of HO8910 cells.

In this study, we also observed that AM significantly increased integrin $\alpha 5$ expression by FACS analysis, indicating a new signaling for AM function. Antibodies of integrin $\alpha 5 \beta 1$ were mainly used to anti-tumors treatment $[19,20]$, especially for the advanced platinum-resistance EOCs [21]. In this study, the blocking antibody was used to illustrate whether integrin $\alpha 5 \beta 1$ was involved in AM induced cell migration. We found that cell migratory rate was decreased in integrin $\alpha 5 \beta 1$ antibody pretreated group compared to single AM treated cells. Also, factors associated with integrin $\alpha 5 \beta 1$ were analyzed in our study. Integrin $\alpha 5 \beta 1$ could consequently activate many cytoskeleton proteins by binding to FN, of which FAK and paxillin were crucial members [22-24]. It was shown that FAK phosphorylation was required for integrin stimulated cell migration by creating a binding site for the Src kinase family. FAK could also phosphorylate paxillin by in vitro and in vivo studies $[25,26]$. Paxillin was a cytoskeletal component involved in integrin signals integration and dissemination. Phosphorylation of paxillin greatly enhanced its function during cell migration [27,28]. Our study showed that exogenous AM treatment enhanced phosphorylation of FAK Tyr397 and paxillin Tyr118. The blocking antibody for integrin $\alpha 5 \beta 1$ mostly inhibited the AM induced upregulation of FAK and paxillin phosphorylation as well. Therefore, in our research, AM promoted HO8910 cells migration probably by upregulating expression of integrin $\alpha 5 \beta 1$ and increasing FAK and paxillin phosphorylation. However, the mechanisms of AM affection on integrin $\alpha 5 \beta 1$ needs further 
A

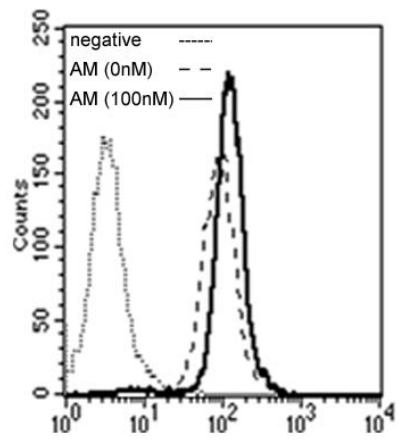

C

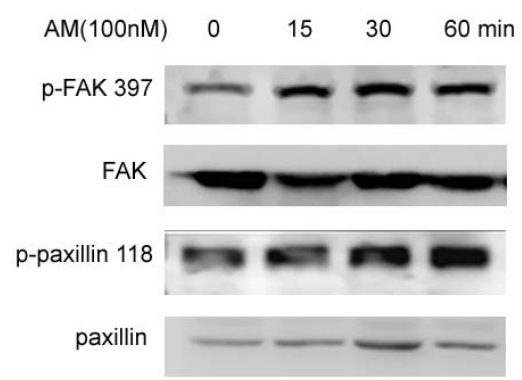

B

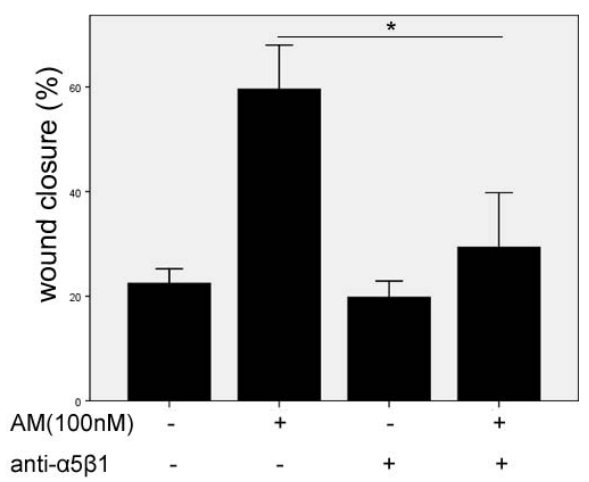

$\mathrm{D}$

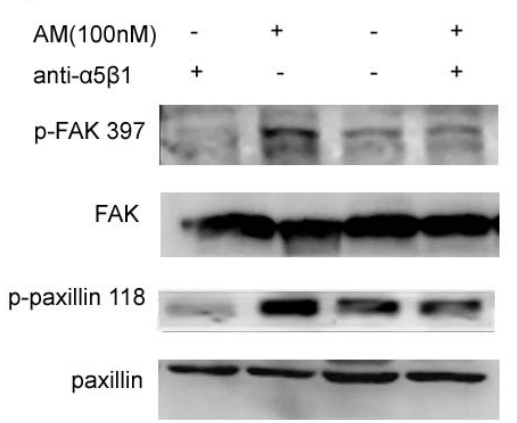

Figure 5 Exogenous AM promoted cell migration with increased integrin $\alpha \mathbf{5} \beta \mathbf{1}$ activation. FACS flow analysis showed increased expression of integrin $\alpha 5$ in AM treated HO8910 cells than in non-treated cells (A). Blocking antibody of integrin $\alpha 5 \beta 1$ inhibited the effect of AM on cell migration (B). Exogenous AM promoted FAK and paxillin phosphorylation at different time point (C). Blocking antibody of integrin $\alpha 5 \beta 1$ abolished the AM promotion on FAK, paxillin phosphorylation (D).

investigation, which might be owing to the enhanced integrin-binding function of talin by AM [29].

\section{Conclusions}

In the summary, we found that high expression of AM contributed to the progression of EOC and indicated poorer prognosis of EOC patients, which further demonstrated its contribution to EOC metastasis probably via integrin $\alpha 5 \beta 1$ mediated cell migration. All of which suggested that AM might play great roles during EOC cell migration, and might be considered as an EOC therapeutic target.

\section{Acknowledgements}

This work was partly supported by the Liaoning Natural Science Foundation (no. 2009225035), the Liaoning Education Foundation (no. 2009A775), and the Shenyang Science and Technology Foundation (no. F11-262-9-14) to Yi Zhang. The authors declared no conflict of interests related to this study.

\section{Author details}

'Department of Gynecology, The First Hospital of China Medical University, Shenyang 110001, China. ${ }^{2}$ Center of Laboratory Technology and
Experimental Medicine, China Medical University, Shenyang 110001, China. ${ }^{3}$ Department of Pathology, The First Hospital and College of Basic Medical Sciences of China Medical University, Shenyang 110001, China. ${ }^{4}$ Department of Orthopaedics, The First Hospital of China Medical University, Shenyang 110001, China.

\section{Authors' contributions}

By $D$ initiated the research, carried out the experiments and wrote the manuscript, $Y Z$ helped with the experimental design and gave funding support, SyZ, YM, ZH and XIZ gave experimental instructions, and FW gave critical review of the manuscript. All authors read and approved the final manuscript.

\section{Competing interests}

The authors declare that they have no competing interests.

Received: 17 January 2012 Accepted: 9 March 2012

Published: 9 March 2012

\section{References}

1. Permuth-Wey J, Sellers TA: Epidemiology of ovarian cancer. Methods Mol Biology (Clifton, NJ) 2009, 472:413-437.

2. Vang R, Shih I-M, Kurman RJ: Ovarian Low-grade and High-grade Serous Carcinoma Pathogenesis, Clinicopathologic and Molecular Biologic Features, and Diagnostic Problems. Adv Anat Pathol 2009, 16(5):267-282.

3. Lengyel E: Ovarian cancer development and metastasis. Am J Pathol 2010, 177(3):1053-1064. 
4. Kitamura K, Kangawa K, Kawamoto M, Ichiki Y, Nakamura S, Matsuo H, Eto T: Adrenomedullin: a novel hypotensive peptide isolated from human pheochromocytoma. Biochem Biophys Res Commun 1993, 192(2):553-560.

5. Wimalawansa SJ: Amylin, calcitonin gene-related peptide, calcitonin, and adrenomedullin: A peptide superfamily. Crit Rev Neurobiol 1997, 11(23):167-239.

6. Zudaire E, Martinez A, Cuttitta F: Adrenomedullin and cancer. Regul Pept 2003, 112(1- 3):175-183.

7. Abasolo I, Montuenga LM, Calvo A: Adremomedullin prevents apoptosis in prostate cancer cells. Regul Pept 2006, 133(1-3):115-122.

8. Martinez A, Vos M, Guedez L, Kaur G, Chen Z, Garayoa M, Pio R, Moody T, Stetler-Stevenson WG, Kleinman HK, et al: The effects of adrenomedullin overexpression in breast tumor cells. J Natl Cancer Inst 2002, 94(16):1226-1237.

9. Hata K, Takebayashi Y, Akiba S, Fujiwaki R, lida K, Nakayama K, Nakayama S, Fukumoto M, Miyazaki K: Expression of the adrenomedullin gene in epithelial ovarian cancer. Mol Hum Reprod 2000, 6(10):867-872.

10. Miller MJ, Martinez A, Unsworth EJ, Thiele CJ, Moody TW, Elsasser T, Cuttitta F: Adrenomedullin expression in human tumor cell lines. Its potential role as an autocrine growth factor. J Biol Chem 1996, 271(38):23345-23351.

11. Giacalone PL, Vuaroqueaux V, Daures JP, Houafic L, Martin PM, Laffargue F Maudelonde T: Expression of adrenomedullin in human ovaries, ovarian cysts and cancers - Correlation with estrogens receptor status. Eur J Obstet Gynecol Reprod Biol 2003, 110(2):224-229.

12. Zhang $Y$, Zhang S, Shang H, Pang X, Zhao Y: Basic fibroblast growth factor upregulates adrenomedullin expression in ovarian epithelial carcinoma cells via JNK-AP-1 pathway. Regul Pept 2009, 157(1-3):44-50.

13. Springer TA, Wang $\mathrm{JH}$ : The three-dimensional structure of integrins and their ligands, and conformational regulation of cell adhesion. Cell Surface Receptors 2004, 68:29.

14. Buczek-Thomas JA, Chen N, Hasan T: Integrin-mediated adhesion and signalling in ovarian cancer cells. Cell Signal 1998, 10(1):55-63.

15. Reuning U: Integrin alpha v beta 3 Promotes Vitronectin Gene Expression in Human Ovarian Cancer Cells by Implicating Rel Transcription Factors. J Cell Biochem 2011, 112(7):1909-1919.

16. Sawada K, Mitra AK, Radjabi AR, Bhaskar V, Kistner EO, Tretiakova M, Jagadeeswaran S, Montag A, Becker A, Kenny HA, et al: Loss of E-cadherin promotes ovarian cancer metastasis via alpha(5)-integrin, which is a therapeutic target. Cancer Res 2008, 68(7):2329-2339.

17. Mitra AK, Sawada K, Tiwari P, Mui K, Gwin K, Lengyel E: Ligandindependent activation of c-Met by fibronectin and alpha(5)beta(1)integrin regulates ovarian cancer invasion and metastasis. Oncogene 2011, 30(13):1566-1576.

18. Morozevich G, Kozlova N, Cheglakov I, Ushakova N, Berman A: Integrin alpha 5 beta 1 controls invasion of human breast carcinoma cells by direct and indirect modulation of MMP-2 collagenase activity. Cell Cycle 2009, 8(14):2219-2225

19. Ramakrishnan V, Bhaskar V, Law DA, Wong MHL, DuBridge RB, Breinberg D, O'Hara C, Powers DB, Liu G, Grove J, et al: Preclinical evaluation of an antialpha5beta1 integrin antibody as a novel anti-angiogenic agent. J Exp Ther Oncol 2006, 5(4):273-286.

20. Ricart AD, Tolcher AW, Liu G, Holen K, Schwartz G, Albertini M, Weiss G, Yazji S, Ng C, Wilding G: Volociximab, a Chimeric Monoclonal Antibody that Specifically Binds alpha(5)beta(1) Integrin: A Phase I, Pharmacokinetic, and Biological Correlative Study. Clin Cancer Res 2008, 14(23):7924-7929.

21. Bell-McGuinn KM, Matthews CM, Ho SN, Barve M, Gilbert L, Penson RT, Lengyel E, Palaparthy R, Gilder K, Vassos A, et al: A phase II, single-arm study of the anti-alpha 5 beta 1 integrin antibody volociximab as monotherapy in patients with platinum-resistant advanced epithelial ovarian or primary peritoneal cancer. Gynecol Oncol 2011, 121(2):273-279.

22. Bearz A, Tell G, Formisano S, Merluzzi S, Colombatti A, Pucillo C: Adhesion to fibronectin promotes the activation of the p125(FAK)/Zap-70 complex in human T cells. Immunology 1999, 98(4):564-568.

23. Shi $Q$, Boettiger D: A novel mode for integrin-mediated signaling: Tethering is required for phosphorylation of FAK Y397. Mol Biology Cell 2003, 14(10):4306-4315.

24. Tanaka T, Yamaguchi $R$, Sabe H, Sekiguchi $K$, Healy JM: Paxillin association in vitro with integrin cytoplasmic domain peptides. FEBS Lett 1996, 399(1-2):53-58.
25. Bellis SL, Miller JT, Turner CE: Characterization of tyrosine phosphorylation of paxillin in-vitro by focal adhesion kinase. J Biol Chem 1995, 270(29):17437-17441.

26. Schaller MD, Otey CA, Hildebrand JD, Parsons JT: Focal adhesion kinase and paxillin bind to peptides mimicking beta-integrin cytoplasmic domains. J Cell Biology 1995, 130(5):1181-1187.

27. Petit V, Boyer B, Lentz D, Turner CE, Thiery JP, Valles AM: Phosphorylation of tyrosine residues 31 and 118 on paxillin regulates cell migration through an association with CRK in NBT-Il cells. J Cell Biology 2000, 148(5):957-969.

28. Tsubouchi A, Sakakura J, Yagi R, Mazaki Y, Schaefer E, Yano H, Sabe H: Localized suppression of RhoA activity by Tyr31/118-phosphorylated paxillin in cell adhesion and migration. J Cell Biology 2002, 159(4):673-683.

29. Kioon M-DA, Asensio C, Ea H-K, Uzan B, Cohen-Solal M, Liote F: Adrenomedullin increases fibroblast-like synoviocyte adhesion to extracellular matrix proteins by upregulating integrin activation. Arthritis Research \& Therapy 2010, 12(5):R190.

doi:10.1186/1756-9966-31-19

Cite this article as: Deng et al:: Adrenomedullin expression in epithelial ovarian cancers and promotes HO8910 cell migration associated with upregulating integrin $\alpha 5 \beta 1$ and phosphorylating FAK and paxillin. Journal of Experimental \& Clinical Cancer Research 2012 31:19.

\section{Submit your next manuscript to BioMed Central and take full advantage of:}

- Convenient online submission

- Thorough peer review

- No space constraints or color figure charges

- Immediate publication on acceptance

- Inclusion in PubMed, CAS, Scopus and Google Scholar

- Research which is freely available for redistribution 